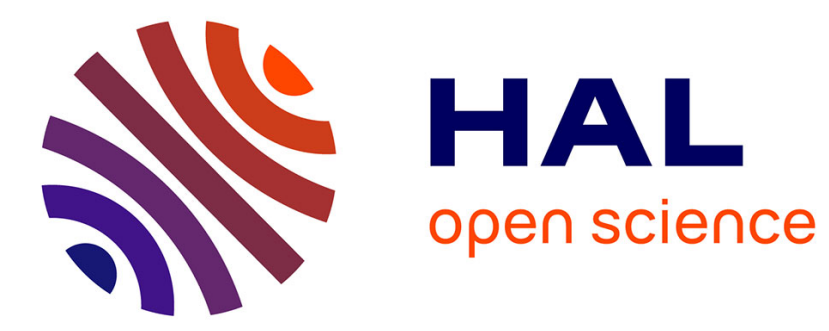

\title{
CHINESE MIGRANTS AND THE "INUNDATION" METAPHOR
}

\author{
Gregory Lee
}

\section{To cite this version:}

Gregory Lee. CHINESE MIGRANTS AND THE "INUNDATION" METAPHOR: Risk, Representation, Repression: Constructing and Manipulating Fear of the Chinese Other. EastAsiaNet Workshop"Framing Risk: Hazard Perceptions as a Crucial Factor in Imagining East Asia", Jun 2007, LUND, Sweden. halshs-00188544

\section{HAL Id: halshs-00188544 https://shs.hal.science/halshs-00188544}

Submitted on 17 Nov 2007

HAL is a multi-disciplinary open access archive for the deposit and dissemination of scientific research documents, whether they are published or not. The documents may come from teaching and research institutions in France or abroad, or from public or private research centers.
L'archive ouverte pluridisciplinaire HAL, est destinée au dépôt et à la diffusion de documents scientifiques de niveau recherche, publiés ou non, émanant des établissements d'enseignement et de recherche français ou étrangers, des laboratoires publics ou privés. 


\section{CHINESE MIGRANTS AND THE “INUNDATION” METAPHOR}

(This paper revisits work originally undertaken in 1992-1994 (and published in Troubadours, Trumpeters, Troubled Makers (Duke UP, 1996) on the metaphors used to disparage and ultimately have excluded Chinese immigrants from the USA. The conclusion attempts to bring up to date the history and theorization of this phenomenon and to illustrate its contemporary global spread. It was presented at an EastAsiaNet research workshop at the University of Lund, Sweden, 2 June 2007 under the title "Risk, Representation, Repression: Constructing and Manipulating Fear of the Chinese Other".)

In the middle of the last century there were a few thousand Chinese who came to supply labour to California. The project to exclude Chinese people from America, from citizenship, from being American started around 1850, and was partly accomplished by 1870, with the Naturalization Act which denied the right to naturalization to Chinese, and nominally concluded with the Exclusion Act of 1882. The campaign was not restricted to nor solely generated by California, but rather was nation-wide, and transcended class and ethnic boundaries. Legislatively the project continued with anti-miscegenation laws, ideologically with the discourse of Yellow Peril. Legal exclusion was prepared for over two or three decades by the transmitters and negotiators of America's social imaginary and dominant ideologies the mass media of the day, the press.

The West Coast has long been demonized as the engine of the movement to exclude the Chinese from America, but it was in fact the influential East Coast newspapers of the nineteenth-century which vociferously led the exclusion campaign. A New York Daily Tribune editorial of Friday, September 29, 1854, alerts the East Coast reader to the "fears" of white Californians:

a carefully constructed enumeration of racial and national "characteristics". Some are specific to the Chinese, the unknowable Oriental. Others are more general racist slurs. They have formed, for much of the last 150 years, the basis for American, and European, dominant perceptions of the Chinese, and the "Oriental": 
They are for the most part an industrious people, forbearing and patient of injury, quiet and peaceable in their habits: say this, and you have said all the good that can be said of them. They are uncivilized, unclean, filthy beyond all conception, without any of the higher domestic or social relations; lustful and sensual in their dispositions; every [italicized in the original text] female is a prostitute, and of the basest order; the first words of English they learn are terms of obscenity or profanity, and beyond this they care to learn no more. Clannish in nature, they will not associate except with their own people....the Chinese quarter of the city is a by-word for filth and sin. Pagan in religion they know not the virtues of honesty, integrity or good faith; and in Court they never scruple to commit the most flagrant perjury. ${ }^{1}$

There is, here, an especially extreme position taken towards women, who to the racist eugenicist present not only the danger of reproduction of the inferior race, but of contamination of the superior race. The psychosocial nexus between the menstrual flow and contamination by an unclean race is imbricated in this particular racist notion. Klaus Theweleit in his book Male Fantasies, traces this connection between metaphors of fluidity and the fear of contamination. "The flood," in German early twentieth-century texts, "seems to flow from the inside of those from whom the constraint of the old order has been removed. Something comes to light that has hitherto been forbidden, buried beneath the surface." ${ }^{2}$

To justify the thesis that the Chinese would be numerically overwhelming, statistics were misrepresented. But primarily, literary metaphors were invoked to represent the size of the potential group of Others. The major trope employed is what I have call the trope of inundation. Unwanted immigrants of color everywhere have frequently been described as "pouring in," "swamping," "flooding in," as coming in "tides" and "waves." In the Tribune editorial, the phobia of

\footnotetext{
${ }^{1}$ New York Daily Tribune, September 29, 1854, page 4.

2 Klaus Theweleit, Male Fantasies (Minneapolis: University of Minnesota Press, 1987) 1231.

3 I recall when I was a young child seeing an elaborate racist, anti-black ditty which intimated that black people were coming to England to scrounge on the white people's welfare state. I can recall one line clearly: "They come here and wash in Tide." There was a play on the word "tide" since "Tide" was, and still is, a popular brand of laundry detergent. There was the implication not only that the Other was entering the country illicitly at the country's seaboard, and thus uncontrolled and in great numbers, but also that he was ignorant of the ways of British society, unused to washing and uninformed as to the difference between toilet
} 
death by drowning in an alien and unclean fluid is invoked. The metaphor alludes to an allied and recurrent image typical of this racist discourse, that of the fear of contamination, the terror of being made unclean by the filthy and sick.

In Theweleit's study of the construction of the fascist, racist narrative which would be concretized in Germany's Nazism, in the 1930s and 1940s, in which the flood is the red flood of bolshevism, "a kind of ocean that surges on in waves, inundating and engulfing," he isolates the power of the inundation metaphor in a discourse of hate which was, of course, quintessentially racist. ${ }^{4}$ One of the examples Theweleit gives, a text by Edwin Erich Dwinger, described Germany's First World War defeat thus:

The whole world poured out over Germany: Americans and New Zealanders, Australians and Englishmen, Portuguese and French. The bitterest pill to swallow was the stationing of blacks everywhere by the French: Moroccans and Senegalese negroes, Indochinese and Turks. $^{5}$

The non-white Other in racist discourse is often constructed as "dirty". Adrian Forty defines dirt as "matter out of place: dirt is the label we attach to what we perceive as disorder, a state that

soap and clothes washing detergent, and thus ultimately inassimilable. Allusions to immigrants flooding into dominantly white societies are still currently employed by those who seek to invoke fears. Jean Marie Le Pen, perhaps the most notorious of Europe's racist ideologues, deploys repeatedly the inundation trope: in his La France est de retour (Paris: Carrère/Lafon, 1985) he claims that "we" are being "pushed out by a veritable human tide" (page 52; cited in Taguieff Face au Racisme 2, 130); more recently that there "is no more integration possible. There is only resistance possible, or sooner or later submersion by invasion" (Présent 13-14 November 1989; cited inPierre-André Taguieff, La force du préjugé : Essai sur le racisme et ses doubles (Paris: Éditions La Découverte (Gallimard/tel), 1987, 132) ; and again in his book L'Espoir (Paris: Albatros, 1989) which holds out the prospect of a dwindling European population to be "rapidly replaced and submerged by foreign populations" (Taguieff Face au racisme 133). However, racist deployment of the trope of inundation is not restricted to the far right. The "respectable" and very bourgeois French Premier Edouard Balladur at the first public meeting of his presidential campaign (February 16, 1995) claimed, as one the successes of his two-year premiership, that "immigrant floods were receding"; cited in Charlie Hebdo, February 22, 1995 page 7.

4 Theweleit, 230.

${ }^{5}$ Edwin Erich Dwinger, "Die Armee hinter Stacheldraht," in Deutches Schicksal , Volume 1 (Jena: 1929) 76. Cited in Theweleit 231. 
is often regarded as threatening." ${ }^{\prime 6}$ In the late nineteenth and early twentieth centuries "people in Europe and America began to find dirt more alarming and to be increasingly anxious about cleanliness."7 In Britain, as Forty demonstrates, this enabled the Victorian middle-classes to categorize the working-classes as "dirty" and thus marked by difference, a difference the Victorians were at pains to emphasize in their design and dress. In America, the Chinese immigrants, who were poor and who worked, were the objects of this fascination and aversion with "dirt".

Christian Enzensberger, defines dirt as "anything that impinges...on the person's anxiously guarded autonomy," to the fear of dirt, he find allied people's fear of decay. "They turn away in fright when something at the bottom moves toward the top...also when a structure dissolves (or the reverse)." After the dirt of decay, there is the "dirt of the mass," and the hatred of "anything that throngs or sprawls, any mass in which they might become caught up and irretrievably lost." ${ }^{8}$ Taguieff in his study of racism has noted the recurrence of the image of the rising tide ("le flot") of "inferior elements (degenerate, mentally deficient: the biosocial 'waste')" which threatens to submerge all of society. ${ }^{9}$ This kind of imagery is frequent in the racist imaginary, especially in the phobia of miscegenation, of "mixed blood".

Seeking to invoke such fears of dirt and contamination, the New York Daily Tribune, depicts a youthful, promising California facing the yellow contagion of "Asiatic hordes" of a decadent, decaying, degenerate Celestial Empire just across the sea:

The youngest of Young America next door to the oldest of nations. ... [with] the densest population on the globe. They are pouring in upon

\footnotetext{
${ }^{6}$ Adrian Forty, Objects Of Desire: Design and Society since 1750 (London \& New York: Thames and Hudson, 1986,1992) 157.

${ }^{7}$ Forty 157.

${ }^{8}$ Christian Enzensberger, Grösserer Versuch über den Schmutz [Expanded Essay on Dirt] (Munich, 1968) 23; cited in Theweleit I, 385.

9 Pierre-André Taguieff, La force du préjugé: Essai sur le racisme et ses doubles (Paris: Éditions La Découverte (Gallimard/tel), 1987) 351.
} 
California. Their great companies are shipping them to that region by thousands as coolies....Already there are 40,000 there, and the cry is still they come. If the tide continues they must yet outnumber whites on the Pacific; and they are not like the European immigration to the Atlantic States, for they have no sympathy with Americans, whether in religion, habits or language. (My italics) ${ }^{10}$

In 1882, the Chinese Exclusion Act passed the House of Representatives with 201 yeas and 37 nays, making it virtually impossible for new Chinese immigrants to enter the country. After the 1882 Exclusion Act had been passed, almost every state in the union went on to pass antimiscegenation laws. The Chinese Exclusion Act was not finally repealed until 1943.

All that was long ago. Perhaps, but the metaphors and imagery used to manipulate and construct anti-Chinese sentiment remains intact. The inundation metaphor is particularly virulent. We seem incapable, journalist and politicians in particular find it impossible to speak of immigrants with any other language.

Let us confine ourselves to some recent examples, some hostile to China, Chinese people, and their immigration, others neutral or even favorable.

In a 2006 San Francisco Chronicle newspaper article on the history of immigration in California, the falsehood is repeated that the Chinese in the $19^{\text {th }}$ century were discriminated against for economic reasons, when in fact American capitalism was demanding cheap labour, and that the real motivation was ideological and necessitated a targeted and specific Other against whose difference the identity of America could be constructed. The headline goes to pains to explain the inundation metaphor, in his instance in the form of a simile:

\section{IMMIGRATION}

Like waves on the shore, people flood into state

From time to time, California has rejected immigrants

\section{WAVES OF IMMIGRATION}

\footnotetext{
10 New York Daily Tribune, September 29, 1854, page 4.
} 
California has repeatedly served as a bellwether for national sentiment about immigration. After its large Chinese-born population coincided with an oversupply of cheap labor in the economic depression of the 1870s, Congress passed the country's first immigration limit, the Chinese Exclusion Act of 1882.

Charles Burress, San Francisco Chronicle Wednesday, May 3, 2006 page B - 3

Elsewhere in the world, China's recent economic expansion has brought with it an extension of the anti-Chinese immigrant discourse. In 2004 an AFP report on Chinese immigration in Russia, republished in the English-language Taipei Times, resorts several times to the water-related metaphors:

Chinese immigrants flood into the Russian Far East

As more than 2 million Russians have left Russia's Far East and Siberia over the past decade in search of better economic conditions in the western regions, Chinese have been flooding in.

"We need the labour force. There are sectors in which they work better than us, agriculture is one of them," conceded the governor.

Fears of Chinese expansion are uppermost in Russians' minds.......

The head of the Primorye region police's migration department, Viktor Plotnikov, said it was an uphill struggle to regulate Chinese immigration.

"If we gave them half a chance, they'd all stay, like salt into water," he said.

But Russian inhabitants are dependant on the flood of cheap Chinese goods.

AFP, VLADIVOSTOK, RUSSIA

Taipei Times, Tuesday, Jan 27, 2004, Page 5

Flooding is almost always undesirable:

\section{Chinese Immigrants Flood Tibet}

Tibet Facts, $\mathrm{N}^{\circ} 1$, Free Tibet Campaign

http://www.freetibet.org/info/facts/fact1.html 
But the association of immigration with waves, tides, and floods now so embedded in the subconscious, so naturalized as a vocabulary of everyday use that it can even be deployed in discourse that sees itself as pro-Chinese:

\section{Miklos Vamos}

Budapest, Hungary

Miklós Vámos is a Hungarian novelist, screenwriter and talk show host.

Hungary Needs Chinese Immigrants.

Hungary has always been a destination for immigrants. After World War II, a weird thing happened -- most of our immigrants turned out to be Hungarians. This was because at that time Hungary lost the bigger part of its territory with the Trianon Peace Treaty. Many Hungarians from behind the new frontiers came back to their country.

The next wave of migration began when the Iron Curtain came down. Most recently, migration occurred when Hungary's neighbors joined the European Union.

These days, there is some speculation that we will invite the Chinese to Hungary. This would help buttress our diminishing populations. Although I do not believe that a flood of Chinese immigrants is imminent, I would not be sad if they came.

Even scientific articles and web sites repeat the easy yet heavily weighted metaphor when producing seemingly objective history. The website of the Agricultural Personnel Management

Program, University of California, reproduced this article:

2/7/04 News Report -- National Journal

\section{Immigration - the endless flood}

by Siobhan Gorman

The Chinese invented illegal immigration as U.S. policy makers tend to think of it today: They were the first to slip across the Mexican border in hopes of improving their lot by working in this country. Aspiring Chinese immigrants, trying to evade racist "Yellow Peril" prohibitions that in 1882 banned such laborers from entering the United States, traveled first to Mexico. There, smugglers would teach them a few words of Spanish, dress them up as Mexican farm workers, and guide them northward. The United States was then making no attempt to regulate the influx of people from Latin America -- and wouldn't begin to regulate it for more than 80 years.

2/7/04 National Journal reproduced on web page of Agricultural Personnel Management Program, University of California, 
In fictional discourse, since Sax Rohmer's invention of FU Manchu, the Yellow Peril has been threatening to invade. In a recent American novel, Flood Tide:A Dirk Pitt Novel by Clive Cussler, the evil Chinese smuggler has hatched a dastardly plot to flood Louisiana. In fact, America had no need of a sinister Chinese to do this, underspending on flood-prevention was solely responsible for the inundation of New Orleans.

Pacific Northwest, 2000. Dirk Pitt@ rescues a beautiful undercover immigration agent from Qin Shang, an insatiably greedy smuggler whose vast fortune is made selling Chinese immigrants into slavery around the globe. Shang's campaign contributions have bought him a collection of powerful U.S. politicians, but Pitt finds the secret behind Shang's vast and mystifying seaport in the Louisiana bayou to be shockingly sinister. From an adrenaline-pumped race against time and tide up the Mississippi River to a desperate dash to recover Chinese treasures, Dirk Pitt faces one of his most formidable foes -- a madman bent on killing hundreds of thousands of innocent men, women, and children with a catastrophic surge of mass destruction. http://www.bookbrowse.com/reviews/index.cfm?book number=281

To turn to Russian media, we find that not only is Chinese immigration on Russian soil resented but also what is seen as China's historical policy of expansionism in South-East Asia and even in Africa:

\section{A Population for Export}

Southeast Asia has been a target of Chinese expansionism since the thirteenth century, when China was conquered by the Mongols and thousands of Chinese fled south. Now ethnic Chinese occupy many leading positions in business throughout Southeast Asia, and the lion's share of the GDP of countries such as Singapore comes from companies run by Chinese entrepreneurs. The authorities in Beijing see Southeast Asia as the southernmost reaches of the Greater China that is centered on Taiwan and mainland China, and by reinforcing its dominance in Southeast Asia, the Chinese government intends to launch the transformation of the People's Republic of China into a superpower.

The future will also likely see a growing flood of Chinese immigrants to Africa. Alexander Gabuyev , Kommersant: Russia's Daily Online 13.03.2007 3:30:12 GMT http://www.kommersant.com/pda/doc.asp?id=748918\#top 
As we might expect, both Taiwan and Hong Kong are depicted as living in permanent fear of death by drowning :

\section{Flood of Chinese feared by HK}

HONG KONG'S chief executive,Tung Chee-hwa, yesterday said he would seek to change the constitution to stop a feared flood of mainland Chinese immigrants stemming from a recent court ruling.

Independent, The (London), May 7,1999 by Stephen Weeks in Hong Kong http://findarticles.com/p/articles/mi qn4158/is 19990507/ai n14235073

Even the Chinese official Chinese new agency when denying the impact of Chinese or Han imigration are trapped in the journalistic language bind. Here a Reuters report cites the New China New Agency and is subsequently cited on a pro-Tibet web site:

\section{China says Tibet not threatened by immigrant tide}

By Jane Macartney

BEIJING, July 23 (Reuter) - Ethnic Tibetans make up the vast majority of people in the remote and troubled Himalayan region and they are not in danger of being swamped by a flood of Chinese immigrants, the Xinhua news agency says.

World Tibet Network News, Monday, July 24, 1995

http://www.tibet.ca/en/wtnarchive/1995/7/24_6.html

\section{DPP lawmakers warn of Chinese immigrant flood}

DPP legislators yesterday warned that opposition-proposed amendments to the Statute Governing the Relations Between the People of the Taiwan Area and the Mainland Area (兩岸人民關係條例) would lead to a flood of Chinese immigrants.

\section{Tsai Ting-I}

The Taipei Times, Friday, May 31, 2002, Page 2

http://www.taipeitimes.com/News/taiwan/archives/2002/05/31/138335

These are a few examples of the continued use of the inundation metaphor. Much work remains to be done, especially in terms of understanding how the spectacular representation of drowning by flood produces manipulable collective fear. 